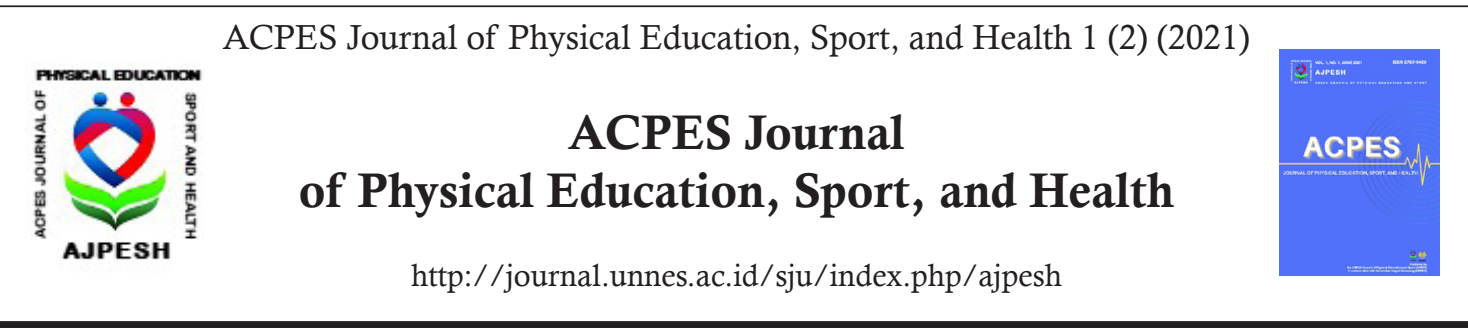

\title{
The Development of Paser Recreational Sports (Final Stage) as a New Attraction in the Cacaban Reservoir Tourism Object, Tegal Re- gency
}

\author{
Dzulfikri Ritonga ${ }^{1 凶}$, Mohammad Arif Ali ${ }^{1}$, Abadi Pitojo ${ }^{2}$, Sahri ${ }^{1}$, \\ Gustiana Mega Anggita ${ }^{1}$, Afan Afghani ${ }^{1}$, Nur Hadziq Haidar ${ }^{1}$
}

${ }^{1}$ Department of Sports Science, Faculty of Sports Science, Universitas Negeri Semarang, Indonesia

${ }^{2}$ Department of Youth, Sports and Tourism, Tegal Regency, Indonesia

DOI: https://doi.org/10.15294/ajpesh.v1i2.50002

\begin{tabular}{|c|c|}
\hline Article Info & Abstract \\
\hline $\begin{array}{l}\text { Article History } \\
\text { Submitted 2021-09-17 } \\
\text { Revised 2021-11-29 } \\
\text { Accepted 2021-12-9 }\end{array}$ & $\begin{array}{l}\text { The development of paser recreational sports (final stage) as a new attraction in the Cacaban } \\
\text { reservoir tourist attraction. Judging from the natural resources and characteristics of the } \\
\text { Cacaban Reservoir, Tegal Regency, the recreational sport of Paser is very suitable to be raised } \\
\text { and developed because it has the potential to make a new attraction in increasing tourist visits. } \\
\text { The purpose of this research is to produce a product that did not exist before, so that it can be }\end{array}$ \\
\hline $\begin{array}{l}\text { Keywords } \\
\text { Paser; Recreational Sports; } \\
\text { Paser Recreational Sports Book }\end{array}$ & $\begin{array}{l}\text { ties. Paser is an event that can become a new attraction in Cacaban Reservoir. This research is } \\
\text { an umbrella research that uses the Research and Development (RnD) method with a sequence } \\
\text { of research stages which are divided into three major stages, consisting of several implementa- } \\
\text { tion procedures, namely: 1) Initial stage, 2) Advanced stage, and 3) Final stage (selected focus } \\
\text { in this article). The results of this development research indicate that the results of the second } \\
\text { stage product expert test scores from the experts can be concluded that the Paser stage II rec- } \\
\text { reational sports book product has an average score of } 3.45 \text { which is included in the "Very Eligi- } \\
\text { ble" category. The conclusion in this study is the development of recreational sports Paser has } \\
\text { the potential to be a new attraction in the Cacaban Reservoir Tourism Object, Tegal Regency. }\end{array}$ \\
\hline
\end{tabular}

\section{INTRODUCTION}

One of the attractions in Tegal Regency that can be used as a sports recreation activity is the Cacaban Reservoir. Cacaban Reservoir was inaugurated by the first president of Indonesia, Ir. Sukarno in 1952 (Disporapar Tegal Regency, 2020). Cacaban Reservoir is a unitary environment of aquatic ecosystems, forest environments, natural reserves and wildlife sanctuaries equipped with beautiful panoramic views (Igunawati, 2010). However, the development in Cacaban Reservoir is still not optimal. This can be seen from the number of visitors to the Cacaban Reservoir, who are relatively few because they do not have their own charm. The most important element in the development of a tourist attraction is a tourist attraction (Gestuti, 2017). The potential that drives the arrival of visitors to a tourist attraction is attraction (Suwntoro in Widagdyo, 2017). Attractiveness is the most important factor in determining the interest of tourists to visit tourist objects (R \& Rozak, 2012).

Basically, one of the indicators of tourism development is facilities and infrastructure (Nugroho et al., 2017; Mandic et al., 2018). The provision of maximum facilities and infrastructure in accordance with the needs of a destination is an important supporting factor to increase tourist visits to a tourist 
attraction (Mustikawati et al., 2017).

Lack of marketing is also one of the factors that influence the lack of interest of tourists because marketing has the aim of forming increased awareness of the importance of maintaining a balance of sustainable development and maintaining the sustainability of cultural, historical, social, economic and natural resource values (Masih, 2019; Ukaj, 2014) Tourism marketing is a way to communicate with visitors through various media (Yulita, 2016).

Management specifically in the development of recreational sports in the Cacaban Reservoir has also not been managed optimally. In developing a tourism object, cooperation or partnership is needed through an approach with related parties which is expected to support the continuation of the development of the tourism object (Kurniawan et al., 2013). If the manager has professional and innovative abilities, he is able to attract tourists to visit the tourist attraction again (Alfiah et al., 2019).

The role of the community is also very influential in supporting the development of tourism objects (Qurniawati, 2019). Active community involvement will provide good value because it is able to provide various kinds of attractions that can be a special attraction (Meray et al., 2016). The involvement and role of the community is very much needed for tourism development which will later be directed to spur increased competitiveness accompanied by community-based development (Astuti, 2015)

The Cacaban Reservoir water area has the potential to hold water sports such as Kayak, Rowing, Jetski, Canoeing, Stand up paddle, Paser and so on as a new attraction. However, when viewed from the characteristics of the natural resources owned by the Cacaban Reservoir, the Paser sport is very suitable to be raised and developed because it has the potential to become a new attraction in the Cacaban Reservoir. "Paser" is a recreational sport that can be competed, the result of a combination of shooting and fishing with fish targets as a substitute for land hunting targets, using air rifles and paser (arrow-shaped bullets) that have been modified as needed, usually carried out in rivers, lakes, swamps, reservoirs, beaches, and water polders, which have conservation and economic value (Paser Mania Tegal, 2020). Apart from that, the recreational sport of Paser can prevent disruption of the ecosystem in the Cacaban reservoir due to the predatory Toman fish that prey on freshwater fish that are hunted by fishermen in the Cacaban Reservoir environment (Arif, 2020).

In the Law of the Republic of Indonesia No. 3 of 2005 concerning the National Sports System, it is also stated that recreational sports are sports carried out by the community with hobbies and abilities that grow and develop in accordance with the conditions and cultural values of the local community for health, fitness and fun (Law Number 3 Concerning the National Sports System, 2005) Recreational sports are directed at promoting sports as an effort to develop public awareness in improving health, fitness, fun and social relations (Fitriantono et al., 2018). In addition, recreational sports are carried out with the aim of filling free time (Nababan et al., 2018).

This study aims to develop the recreational sport of Paser as a new attraction in the Cacaban Reservoir tourist attraction, Tegal Regency.

\section{METHODS}

This research is an umbrella research project that uses a defined Research and Development $(\mathrm{RnD})$ method as a research method that produces a product in the form of a new model or module in a particular field of expertise followed by a certain output product that has the effectiveness of a product. (Saputro, 2017). This research project is divided into three major stages, consisting of several implementation procedures, namely 1) the initial stage (product design and stage I expert test) is the stage carried out by research partner Afan Afghani, 2) the advanced stage (input of the results of the expert test stage I, revision, expert test phase II) was carried out by a research colleague, namely Nur Hadziq Haidar, 3) The final stage (revision of expert test phase II, final product) was the focus of the researcher himself. In this development using a procedural development model. The data in this study are qualitative data in the form of input and suggestions from questionnaires that have been filled out by expert validators. The experts involved are sports experts, Paser recreational sports experts, tourism experts, and language experts.

\section{RESULTS AND DISCUSSION}

The Paser recreational sport development procedure follows the steps that have been modified 
according to development needs as follows:

\section{Finding potential and problems}

There is a problem of lack of visitor interest in the Cacaban Reservoir Tourism Object. Through Paser, both recreational and event, it is hoped that it can become a new attraction that can increase visitor interest in the Cacaban Reservoir Tourism Object.

Table 1. Recapitulation of contents of Paser rekreasi recreational sports book products

\begin{tabular}{|c|c|}
\hline $\begin{array}{l}\text { Paser sports book table of } \\
\text { contents }\end{array}$ & Contents \\
\hline $\begin{array}{l}\text { CHAPTER I History and } \\
\text { Development of Paser }\end{array}$ & $\begin{array}{l}\text { This chapter discusses the history, definition, organization, legal } \\
\text { basis, and list of Paser clubs in Indonesia. }\end{array}$ \\
\hline $\begin{array}{l}\text { CHAPTER II Paser Recre- } \\
\text { ational Sports Facilities and } \\
\text { Infrastructure }\end{array}$ & $\begin{array}{l}\text { This chapter discusses the feasibility of facilities and infrastructure } \\
\text { to support Paser recreational sports activities. }\end{array}$ \\
\hline $\begin{array}{l}\text { CHAPTER III Components } \\
\text { of Marketers' Physical Con- } \\
\text { ditions }\end{array}$ & $\begin{array}{l}\text { This chapter discusses the components of the physical condition } \\
\text { of sports in general, the components of physical conditions that } \\
\text { must be possessed by marketers, and some basics in doing Paser } \\
\text { recreational sports. }\end{array}$ \\
\hline $\begin{array}{l}\text { CHAPTER IV Classification } \\
\text { of Paser Recreational Sports }\end{array}$ & $\begin{array}{l}\text { This chapter discusses Paser which is a recreational sport and } \\
\text { Paser is a competition. }\end{array}$ \\
\hline $\begin{array}{l}\text { CHAPTER V Promotional } \\
\text { Media for Recreational } \\
\text { Sports Paser }\end{array}$ & $\begin{array}{l}\text { This chapter discusses the promotion of Paser recreational sports } \\
\text { to introduce Paser recreational sports to the wider community. }\end{array}$ \\
\hline $\begin{array}{l}\text { CHAPTER VI Economic } \\
\text { Value and Sustainability Po- } \\
\text { tential of Paser Recreational } \\
\text { Sports }\end{array}$ & $\begin{array}{l}\text { This chapter discusses the economic value of the Paser recreation- } \\
\text { al sport and the sustainability of the Paser recreational sport in the } \\
\text { Cacaban Reservoir as a new attraction to increase tourist visits. }\end{array}$ \\
\hline
\end{tabular}

\section{Conducting data collection on Paser recreational sports information}

Information data collection was obtained from literature studies and consultations with experts. This stage is carried out to find out and collect information needs for product design planning as a result of development (Paser recreational sport) in several ways, namely: 1) Field studies conducted to determine the need for development of Paser recreational sports by analyzing the potential of natural resources in the object. Cacaban Reservoir Tourism; 2) Conducting interviews with interested parties such as Paser Mania Tegal (PMT), the Indonesian Fish Marketers Association (PPII) and the Tegal Regency Youth, Sports and Tourism Office,

\section{Design product design}

At this stage the information that has been obtained is used as content material in the product in the form of a Paser recreational sports book. The material contained in the Paser recreational sports book can be seen in Table 1 Recapitulation of the contents of the Paser recreational sports book product content.

\section{Product expert test}

The design expert test is carried out using electronic mail media in two stages in which the expert test questionnaire is included as a product feasibility assessment form. Several experts/experts were involved in this process, including: 1) Expert in sports (Gustiana Mega Anggita, S.Pd. Jas., M.Or.); 2) Paser expert (Christian Ardita); 3) Tourism expert (Ahmad Abdul Khasib, SE, MH), and 4) Linguistic expert (Riyadi Widhiyanto, S.Pd.). The expert test stage is carried out so that the feasibility of the product developed can be determined based on the assessment of the expert. Then from the expert test, comments and suggestions were obtained that were used to complete the information on the product. The product expert test scores are divided into 4 categories as presented in Table 2. 
Dzulfikri Ritonga et al. / AJPESH 1 (2) (2021)

Table 2. Product expert test scores

\begin{tabular}{ll}
\hline INTERVAL & CATEGORY \\
\hline $3<$ SCORE 4 & Very Worthy \\
$2<$ SCORE 3 & Worthy \\
$1<$ SCORE 2 & Decent enough \\
1 & Not feasible \\
\hline
\end{tabular}

\section{Stage I expert test results}

The first phase of the expert test was carried out by an umbrella research partner (Afan Afghani provided validation and Nur Hadziq Haidar revised input from the validator). This stage has the aim of getting comments and suggestions and knowing the shortcomings of the Paser recreational sports book product in order to maintain the feasibility of the product. The results of the first stage of the expert test are as follows:

\section{Sports expert test results}

Conducted by Gustiana Mega Anggita, S.Pd. Jas., M.Or. as a Lecturer in the Department of Sports Science, State University of Semarang on Tuesday, July 13, 2021, by providing five points of input, namely: 1) The book can actually be developed in more detail about paser recreational sports. It is better in the book to be sent to understand first what paser sport is, more towards defining essentially what paser is so that ordinary people can understand what is meant; 2) In the component chapter of better physical condition, the dominant physical condition in paser sports is numbered; 3 ) There needs to be a technical chapter or sub-chapter for implementing sports such as game rules or competitions or competitions; 4) Facilities and infrastructure can also be explained in more detail if there is information on the characteristics of rivers or reservoirs or lakes that are suitable for this sport. It seems that this also includes extreme sports, there are also buoys that are used, if there is a standard what must be owned, it is better to be informed in a book, for example softball, the bat used must have a certificate or label from the ISF (International Softball Federation), and 5) Can also added information about injuries that are often experienced and the types of first aid that can be done. All necessary input and suggestions are entered into the Paser recreational sports book. The results of the expert test in the field of sports in stage I obtained an average score of 2.35 which was included in the "Eligible" category with the conclusion that it could be used with many improvements.

\section{Paser recreational sport expert test results}

Conducted by the Secretary of the Indonesian Fish Marketers Association (PPII) Christian Ardita on Friday 09 July 2021 who has a background in accordance with the material developed. The field of recreational sports, Paser, provides 2 input points, namely: 1) Emphasis on social goals that can be further elaborated, such as socali activities and social services, so that people will understand and can feel the presence of the marketers who are members of the PPII forum, and 2 ) Emphasis for our goals and objectives to reduce or divert land hunters, in this case the game is increasingly rare and has been protected, to switch to being marketers with FISH game animals, which are still abundant and mostly can be consumed by the whole family compared to the results land hunt. All necessary input and suggestions are entered into the Paser recreational sports book. The results of the expert test in the field of recreational sports, Paser stage I, obtained an average score of 3.47 which was included in the "Very Eligible" category with the conclusion that it could be used with slight improvements.

\section{Tourism expert test results}

Conducted by Ahmad Abdul Khasib, SE, MH as Chair of the UPTD for Tourism Object Management of the Youth, Sports and Tourism Office of Tegal Regency on Friday, July 9, 2021 by providing three input points, namely: 1) Exploration of natural potential as the basic element behind the establishment of the fish paser sport needs to be intensive and comprehensive deepening combined with the basic principles of tourism (attarction, accessibility and amenities) so that it is directly proportional to the essence of the sport "RECREATION"; 2) The structure and mechanics of the competition were re-sharpened such as scoring, categories and other competition rules, and 3) There is no empirical explanation either in the laboratory or in facts in the field related to the safety and comfort 
of using an air rifle (fish paser tool). All necessary input and suggestions are entered into the Paser recreational sports book. The results of the first stage of the tourism expert test obtained an average score of 2.88 which was included in the "Eligible" category with the conclusion that it could be used with slight improvements.

\section{The results of the expert test in the field of linguistics}

It was carried out by Riyadi Widhiyanto as an Indonesian language teacher at SMP Negeri 01 Ungaran on Sunday, July 18, 2021 by providing one input point, namely "It is necessary to add some parts of the book that do not yet exist, such as instructions for using books and summaries (if any)". Feedback and suggestions have been entered into the Paser recreational sports book. The results of the stage I linguistic expert test obtained an average score of 3.82 which was included in the "Very Eligible" category with the conclusion that it could be used with slight improvements.

Based on the results of the expert test scores of Phase I products from the sports, Paser recreational sports, tourism, and linguistic fields, it can be concluded that the Paser Phase II recreational sports book products have an average score of 3.13 which is included in the "Very Eligible" category.

\section{Stage II expert test results}

This stage is the focus of the researcher (providing a phase II product feasibility assessment form and revising if there are suggestions or input from experts). This stage has the aim of maintaining the consistency and feasibility of the Paser recreational sports guidebook product. The results of the second phase of the expert test are as follows:

\section{Sports expert test results}

Conducted by Gustiana Mega Anggita, S.Pd. Jas., M.Or. as Lecturer of the Department of Sports Science, Semarang State University on Wednesday, July 21, 2021 without any comments and suggestions so that there will be no revision. The results of the second stage of the sports expert test obtained an average score of 2.76 which was included in the "Eligible" category with the conclusion that it could be used without improvement.

\section{Paser recreational sports expert test results}

Conducted by the Secretary of the Indonesian Fish Marketers Association (PPII) Christian Ardita on Sunday, July 18, 2021 without any comments and suggestions so that there will be no revisions. The results of the expert test in the field of recreational sports, Paser stage II, obtained an average score of 3.64 which was included in the "Very Eligible" category with the conclusion that it could be used without improvement.

\section{Tourism expert test results}

Conducted by Ahmad Abdul Khasib, SE, MH as Chair of the UPTD Tourism Object Management Office of Youth, Sports and Tourism Tegal Regency on Sunday, July 18, 2021 with the comment "The revision of the material is very significant making this book more complete, easy to understand and worthy of being a reference for sports development recreation that is integrated into tourist attractions so that healthy and happy slogans become a fun integration in the current millennial era". The results of the second stage of the tourism expert test obtained an average score of 3.52 which was included in the "Very Eligible" category with the conclusion that it could be used without improvement.

\section{The results of the expert test in the field of linguistics}

Conducted by Akhmad Bahtiar Rifai, S.Pd as an Indonesian teacher at SMK Al Fajar Lebaksiu Tegal on Sunday 18 July 2021 with comments Overall the presentation of the book is good and in accordance with the specified criteria/aspects. The results of the second stage linguistic expert test obtained an average score of 3.88 which was included in the "Very Eligible" category with the conclusion that it could be used without improvement.

Based on the results of the second stage product expert test scores from the sports, Paser recreational sports, tourism, and linguistic fields, it can be concluded that the Paser stage II recreational sports book product has an average score of 3.45 which is included in the "Very Eligible" category. 


\section{CONCLUSION}

The development of the Paser recreational sport has the potential to become a new attraction in the Cacaban Reservoir Tourism Object, Tegal Regency. This potential is described through the history, development and infrastructure of paser recreational sports related to the natural conditions that exist in the Cacaban Reservoir. Apart from that, based on the results of product expert tests, the product of development research (Paser recreational sports book) can be used as a support in carrying out Paser activities both recreational and competitive, especially in the Cacaban Reservoir Tourism Object.

\section{ACKNOWLEDGEMENT}

This research is part of an umbrella research project conducted by Moh Arif Ali in 2021 with members: 1) Afan Afghani; 2) Nur Hadziq Haidar, and 3) Dzulfikri Ritonga. This research is also an implementation of collaborative activities carried out by the Faculty of Sports Science with Paser Mania Tegal with evidence of the cooperation document, namely the Implementation Agreement with number 451/un37.1.6/TU-IKOR/2021 which was signed by the Head of the Department of Sports Science, Faculty of Sports Science, State University. Semarang (Sugiarto, S.Si., M.Sc.) and the Head of Paser Mania Tegal (Muhamad Arif).

\section{REFERENCES}

Alfiah, S., Andriani, J., Lesmana, R., Sunardi, N. \&, \& Furyanah, A. 2019. Manajemen Pengelolaan Desa Wisata pada Desa Cimanggu, Kecamatan Cisalak, Kabupaten Subang, Provinsi Jawa Barat (Studi Kasus pada Curug Paok dan Bukit Pasir Jaka) \{Management of Tourism Village Management in Cimanggu Village, Cisalak District, Subang Regency, West Java Province (Case Study on Curug Paok and Bukit Pasir Jaka)\}. Jurnal Abdi Masyarakat: Humanis (Servant of the Humanist Society Journal), 1 (1): 21-28. http://openjournal.unpam.ac.id/index.php/ $\mathrm{JAMH} /$ article/view/3377

Arif, M. 2020. Ikan Predator Luar Jawa Ancam Ekosistem Waduk Cacaban (Predator Fish Outside Java Threats Cacaban Reservoir Ecosystem). Radartegal.com. Retrieved from https://radartegal.com/ ikan-predator-luar-jawa-ancam-ekosistem-waduk-cacaban.829.html

Astuti, M.T. 2015. Potensi Wisata Olahraga dalam Meningkatkan Kunjungan Wisatawan (The Potential of Sports Tourism in Increasing Tourist Visits). Jurnal Kepariwisataan Indonesia (Indonesian Journal of Tourism), 10 (1): 31-40. https://www.kemenparekraf.go.id/asset_admin/assets/ uploads/media/old_all/JKI\%20Vol_10\%20No_1\%202015\%20-\%20Potensi\%20Wisata\%20 Olah\%20Raga\%20Dalam\%20Meningkatkan\%20Kunjungan\%20Wisatawan.pdf

Fitriantono, M.R., Kristiyanto, A. \& Siswandari, S. 2018. Potensi Alam untuk Olahraga Rekreasi (Nature's Potential for Recreational Sports). Prosiding Seminar Nasional Iptek Olahraga (SENALOG) (Proceedings of the National Sports Science and Technology Seminar), 1 (1): 9-11. https:// ejournal.unibabwi.ac.id/index.php/semnassenalog/article/view/156

Gestuti, S.S. 2017. Marketing Mix Museum Gula Gondang Baru Klaten dalam Meningkatkan Jumlah Wisatawan (Marketing Mix of Gondang Baru Sugar Museum Klaten in Increasing the Number of Tourists). Jurnal Penelitian dan Pengabdian Masyarakat Jurnal Hotelier (Hotelier Journal, Indonesian Polytechnic Surakarta), 3 (2): 1-12. Retrieved from http://hotelier.poltekindonusa. ac.id/index.php/view/article/view/59/46

Igunawati, D. 2010. Analisis Permintaan Objek Wisata Tirta Wadu Cacaban, Kabupaten Tegal (Analysis of Demand for Tourism Objects Tirta Cacaban Reservoir, Tegal Regency). Undergraduate Thesis. Semarang: Diponegoro University. https://core.ac.uk/download/pdf/11721991.pdf

Kurniawan, F., Zauhar, S. \& Hermawan. 2013. Kemitraan Pengelolaan Sektor Pariwisata (Studi pada Tirta Wisata Kabupaten Jombang) (Tourism Sector Management Partnership). Jurnal Administrasi Publik (Journal of Public Administration (JAP)), 1 (1): 47-55. http://administrasipublik. studentjournal.ub.ac.id/index.php/jap/article/view/10

Mandic, A., Mrnjavac, Z. \& Kordic, L. 2018. Tourism Infrastructure, Recreational Facilities and Tourism Development. Tourism and Hospitality Management, 24 (1): 1-22. http://dx.doi. org/10.20867/thm.24.1.12

Masih, I. 2019. Pengembangan Desa Wisata oleh Pemerintah Desa Babakan Kecamatan Panganda- 
ran Kabupaten Pangandaran (Tourism Village Development by the Babakan Village Government, Pangandaran District, Pangandaran Regency). Dinamik: Jurnal Ilmiah Ilmu Administrasi Negara (Dynamics: Scientific Journal of State Administration), 53 (9): 1689-1699. https://jurnal. unigal.ac.id/index.php/dinamika/article/view/2806

Meray, J.G, Tilaar, S. \& Takumansang, E.D. 2016. Partisipasi Masyarakat terhadap Pengembangan Pariwisata Pantai Mahembang Kecamatan Kakas (Community Participation in the Development of Mahembang Beach Tourism, Kakas District). Spasial: Perencanaan Wilayah dan Kota (Spatial: Urban Regional and Planning), 3 (3): 47-55. https://ejournal.unsrat.ac.id/index.php/ spasial/article/view/13429

Mustikawati, T.A., Pangestuti, E. \& Sunarti. 2017. Analisis Pengembangan Sarana Prasarana Obyek Wisata Alam Telaga Ngebel dalam Meningkatkan Kesejahteraan Ekonomi Masyarakat (Analysis of the Development of Infrastructure Facilities for the Natural Tourism Object of Ngebel Lake in Improving the Economic Welfare of the Community). Jurnal Administrasi Bisnis (Journal of Business Administration), 53 (2): 1-10. http://administrasibisnis.studentjournal.ub.ac.id/ index.php/jab/article/view/2202/2598

Nababan, M.B., Dewi, R. \& Akhmad, I. 2018. Analisis Pola Pembinaan dan Pengembangan Olahraga Rekreasi di Federasi Olahraga Rekreasi Masyarakat Indonesia Sumatera Utara Tahun 2017 (Analysis of Patterns of Coaching and Development of Recreational Sports in the Indonesian Society of Recreational Sports Federation of North Sumatra 2017). Jurnal Pedagogik Olahraga (Journal of Sports Pedagogy), 4 (1): 38-55. https://jurnal.unimed.ac.id/2012/index.php/jpor/ article/download/11963/10421

Nugroho, I., Listiyono, H. \& Anwar, S.N. 2017. Perancangan Unified Modelling Language Aplikasi Sarana Prasarana Pendukung Pariwisata Kota Semarang (Unified Modeling Language Design of Semarang City Tourism Supporting Infrastructure Applications). Prosiding Seminar Nasional Multi Disiplin Ilmu (Joint Proceedings), 2 (1): 90-95. Retrieved from https://media.neliti.com/media/ publications/174473-ID-perancangan-unified-modelling-languageap.pdf

Paser Mania Tegal. 2020. PMT Exposure to the Head of Services.

Qurniawati, R.S. 2019. Analisis Pengembangan Pariwisata berdasarkan Dukungan Masyarakat di Temanggung (Analysis of Tourism Development based on Community Support in Temanggung). Daya Saing: Jurnal Ekonomi Manajemen Sumber Daya (Competitiveness: Journal of Resource Management Economics), 21 (2): 88-97. https://journals.ums.ac.id/index.php/dayasaing/article/ download/6786/5176

R, B., \& Rozak, H.A. 2012. Kualitas Daya Tarik Wisata, Kepuasan dan Niat Kunjungan Kembali Wisatawan Mancanegara di Jawa Tengah (Quality of Tourist Attraction, Satisfaction and Intention of Return Visits of Foreign Tourists in Central Java). Dinamika Kepariwisataan (Scientific Journal of Tourism Dynamics), 11 (2): 1-12. https://www.unisbank.ac.id/ojs/index.php/pdk1/ article/view/1715

Saputro, B. 2017. Research \& Development Management for Thesis and Dissertation Writers (Vol. 53). Yogyakarta.

Ukaj, F. 2014. Development of a Tourist Destination based on Marketing Activities. Academic Journal of Interdisciplinary Studies, 3 (2): 141-146. https://www.richtmann.org/journal/index.php/ajis/ article/view/2959/2919

Widagdyo, K.G. 2017. Pemasaran, Daya Tarik Ekowisata, dan Minat Berkunjung Wisatawan (Marketing, Ecotourism Attractiveness, and Tourist Visiting Interest). Esensi: Jurnal Bisnis dan Manajemen (Essence: Journal of Business and Management), 7 (2): 261-276. https://doi.org/10.15408/ ess.v7i2.5411

Yulita, H. 2016. Pengaruh Bauran Pemasaran Pariwisata terhadap Keputusan untuk Berkunjung (The Effect of Tourism Marketing Mix on Decisions to Visit). Jurnal Hospitality dan Pariwisata (Journal of Hospitality and Tourism), 2 (2): 165-183. https://journal.ubm.ac.id/index.php/hospitality-pariwisata/article/download/903/799 